\title{
Guillain-Barre syndrome associated with Norovirus infection
}

\author{
Khalid Gailani Eltayeb, Paul Crowley \\ Neurology Department, Waterford Regional Hospital, Waterford, Ireland \\ Correspondence to Dr Khalid Gailani Eltayeb Registrar, drkg72@gmail.com
}

\section{Summary}

The authors describe a case of Guillain-Barre syndrome after the diarrhoeal infection due to Norovirus. Many infections have been described most notably Campylobacter jejuni. To our knowledge a connection to Norovirus has not been described in the world literature. The authors speculate on why this may be so.

\section{BACKGROUND}

This is, to our best knowledge, the first case of norovirusassociated Guillain-Barre syndrome (GBS) case reported in the literature.

\section{CASE PRESENTATION}

A 46-year-old female, care-assistant was admitted to hospital with back pain and progressive ascending weakness and numbness of all four limbs. She worked in a nursing home with a proven outbreak of Norovirus diarrhoea; 13 residents had confirmed infection. She described a $36 \mathrm{~h}$ episode of vomiting and diarrhoea, 10 days before admission, which settled spontaneously. Her stool on admission was positive by PCR testing for Norovirus.

Neurological examination showed mild facial weakness, power of grade 4/5 (MRC Scale) in all four limbs with hyporeflexia and no objective sensory deficit. There was cerebrospinal fluid cytoalbumin dissociation with protein of $0.9 \mathrm{~g} / \mathrm{dl}$. She deteriorated with progressive weakness and respiratory failure necessitating intensive care unit admission and ventilation for 5 days. Her hospital stay was complicated with autonomic dysfunction.

\section{INVESTIGATIONS}

Serology for Campylobacter jejuni, ${ }^{1}{ }^{2}$ Epstein-Barr virus, ${ }^{3}$ cytomegalovirus, herpes zoster virus, hepatitis A, B and $\mathrm{C}$ as well as Venereal Disease Research Laboratory was all negative. Antiganglioside antibody testing (including GM1, GM2, GD1a, GD1b and GQ1b) was negative. Stool culture for Norovirus as well as PCR test were both positive. Neurophysiology findings were consistent with an acquired demyelinating polyneuropathy and supported the diagnosis of GBS.

\section{TREATMENT}

She was treated with a 5 day course of intravenous immunoglobulin at 0.4 grams $/ \mathrm{kg} /$ day.

\section{OUTCOME AND FOLLOW-UP}

She was hospitalised for 12 weeks including a period of rehabilitation. Her recovery was complicated by significant pain requiring opiate analgesia. She has made a good recovery.

\section{DISCUSSION}

We report a case of GBS, which was temporally associated with Norovirus infection. She contracted this in a welldocumented outbreak in a Nursing Home. Norovirus DNA was found by PCR in her stool. The timing suggests that Norovirus was the triggering organism. None of the other usual triggering organisms were found. While another trigger could have been the culprit, this does not seem plausible. We believe that this is the first documented report of a causal association with Norovirus.

Given that Norovirus is so common, it comes as a surprise that an association with GBS was not reported before. The link is therefore either real or spurious. If it is real there are a few reasons why the link was not established. The serology of Norovirus is technically difficult and not checked in routine clinical practice. In shortlived diarrhoeal illnesses, the PCR test for Norovirus may not be checked or may be negative when sought at the time of the onset of GBS (10 to 14 days later). It is possible that the immunological link is different (timing, location, IgA response etc.) and requires a unique set of circumstances to occur. Host factors may play a role, as yet undefined, in this process. This link may stimulate discussion of putative pathophysiological mechanisms (including molecular mimicry ${ }^{4}$ ) which might increase our understanding of what remains an important and dangerous disease.

Noroviruses ${ }^{5}$ belongs to the Caliciviridae family, causes nearly 50 per cent of all outbreaks of acute infectious, non-bacterial gastroenteritis in the USA. ${ }^{6}$ The diagnosis is suggested by acute diarrhoea and/or vomiting in a community outbreak setting. Noroviruses may be identified in stool specimens, and antibody can be measured in serum samples by immune electron microscopic or immunoassay techniques. This is usually not available in routine clinical practice. 


\section{BMJ Case Reports}

\section{Learning points}

- GBS was associated with a definite case of Norovirus infection, which we speculate was causative.

- It is not clear why such a common infection should only trigger this response.

- Norovirus serology is not available in routine clinical practice which may explain, in part, why this association has not been found to date.

Acknowledgements To Dr Brian Casey, Consultant Microbiologist, Waterford Regional Hospital, Ireland.

Competing interests None.

Patient consent Obtained.

\section{REFERENCES}

1. Kuwabara S, Ogawara K, Misawa S, et al. Does Campylobacter jejuni infection elicit "demyelinating" Guillain-Barre syndrome? Neurology 2004:63:529-33.

2. Jacobs BC, Rothbarth PH, van der Meché FG, et al. The spectrum of antecedent infections in Guillain-Barré syndrome: a case-control study. Neurology 1998;51:1110-5.

3. Winer JB, Hughes RA, Anderson MJ, et al. A prospective study of acute idiopathic neuropathy. II. Antecedent events. J Neurol Neurosurg Psychiatr 1988;51:613-8.

4. Ang CW, Jacobs BC, Laman JD. The Guillain-Barré syndrome: a true case of molecular mimicry. Trends Immunol 2004;25:61-6.

5. Cubit WD, Black low NR, Herrmann JE, et al. Antigenic relationships between human caliciviruses and Norwalk virus. J Infect Dis 1987;156:806.

6. Kaplan JE, Gary GW, Baron RC, et al. Epidemiology of Norwalk gastroenteritis and the role of Norwalk virus in outbreaks of acute nonbacterial gastroenteritis. Ann Intern Med 1982; 96:756-61.

This pdf has been created automatically from the final edited text and images.

Copyright 2012 BMJ Publishing Group. All rights reserved. For permission to reuse any of this content visit http://group.bmj.com/group/rights-licensing/permissions.

BMJ Case Report Fellows may re-use this article for personal use and teaching without any further permission.

Please cite this article as follows (you will need to access the article online to obtain the date of publication).

Eltayeb KG, Crowley P. Guillain-Barre syndrome associated with Norovirus infection. BMJ Case Reports 2012;10.1136/bcr.02.2012.5865, Published XXX

Become a Fellow of BMJ Case Reports today and you can:

- Submit as many cases as you like

- Enjoy fast sympathetic peer review and rapid publication of accepted articles

- Access all the published articles

- Re-use any of the published material for personal use and teaching without further permission

For information on Institutional Fellowships contact consortiasales@bmjgroup.com

Visit casereports.bmj.com for more articles like this and to become a Fellow

Keep up to date with all published cases by signing up for an alert (all we need is your email address) http://casereports.bmj.com/cgi/alerts/etoc 